\title{
The Elementary Chemical Composition of Marine Organisms
}


This page intentionally left blank 


\section{MEMOIR}

SEARS FOUNDATION FOR MARINE RESEARCH

\section{Number II}

$\mathbb{T H E} \mathbb{E} \mathbb{E} \mathbb{E} \mathbb{E} \mathbb{N} \mathbb{A} R \mathbb{Y}$ CHIEMIICAL

COMPOSITION<smiles>[O]</smiles>
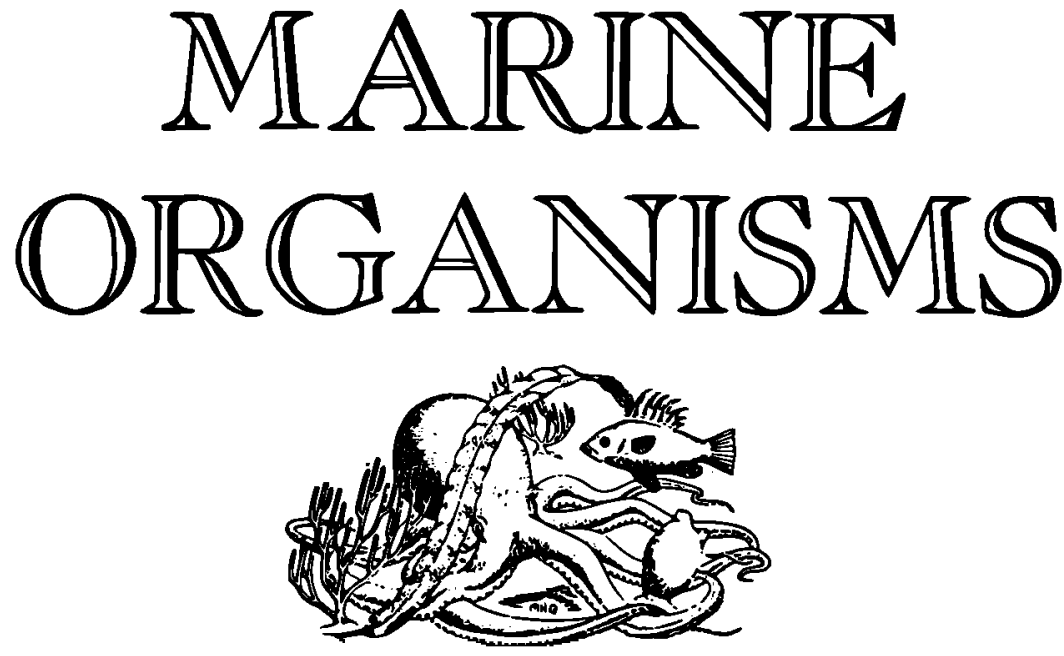

A. P. VINOGR ADOV

VERNADSKy Laboratory For GeOchemical Problems Moscow, U.S.S.R. 


\section{PUBLICATIONS OF THE SEARS FOUNDATION FOR MARINE RESEARCH, YALE UNIVERSITY}

The Sears Foundation for Marine Research at Yale University was established in 1937 by Albert E. Parr, director of Yale's Bingham Oceanographic Laboratory, through a gift from Henry Sears, to promote research and publication in marine sciences. The Foundation's Memoirs, inaugurated in 1948, remain important references. In 1959 the Bingham Oceanographic Collection was incorporated into the Yale Peabody Museum of Natural History.

Distributed by Yale University Press www.yalebooks.com I yalebooks.co.uk

\section{MEMOIR I}

FISHES OF THE WESTERN NORTH ATLANTIC

Part One

Lancelets, Cyclostomes, Sharks

Part Two

Sawfishes, Guitarfishes, Skates and Rays, Chimaeroids

Part Three

Soft-rayed Bony Fishes: Orders Acipenseroidei, Lepisostei, and Isospondyli

Sturgeons, Gars, Tarpon, Ladyfish, Bonefish, Salmon, Charrs, Anchovies, Herring, Shads, Smelt, Capelin, et al.

Part Four

Soft-rayed Bony Fishes: Orders Isospondyli and Giganturoidei Argentinoids, Stomiatoids, Pickerels, Bathylaconids, Giganturids

Part Five

Orders Iniomi and Lyomeri

Lizardfishes, Other Iniomi, Deepsea Gulpers

Part Six

Orders Heteromi (Notacanthiformes), Berycomorphi (Beryciformes), Xenoberyces (Stephanoberyciformes), Anacanthini (Gadiformes) Halosauriforms, Killifishes, Squirrelfishes and Other Beryciforms,

Stephanoberyciforms, Grenadiers

Part Seven

Order Iniomi (Myctophiformes)

Neoscopelids, Lanternfishes, and Atlantic Mesopelagic Zoogeography

Part Eight

Order Gasterosteiformes

Pipefishes and Seahorses

Part Nine, Volume One

Orders Anguilliformes and Saccopharyngiformes

Part Nine, Volume Two

Leptocephali

Part Ten

Order Beloniformes

Needlefishes, Sauries, Halfbeaks, and Flyingfishes

MEMOIR II

THE ELEMENTARY CHEMICAL COMPOSITION OF MARINE ORGANISMS

by A. P. Vinogradov 


\section{The Elementary Chemical Composition of Marine Organisms}

Translated from Vinogradov's original Russian by Julia Efron and Jane K. Setlow, with bibliography edited and newly enlarged by Virginia W. Odum, for the

SURVEY OF EXISTING KNOWLEDGE OF BIOGEOCHEMISTRY AMERICAN MUSEUM OF NATURAL HISTORY 


\section{Yale}

ISBN 978-1-933789-22-4 (pbk.)

ISBN 978-1-933789- 35-4 (e-book)

Issued in paperback by the

Peabody Museum of Natural History, Yale University, New Haven, Connecticut 06511 USA

First published in hardcover in 1953 by the Sears Foundation for Marine Research Bingham Oceanographic Laboratory, Yale University

ISBN 978-0-912532-93-6 (cloth)

Library of Congress Control Number: 55001070

Distributed by Yale University Press

NEW HAVEN AND LONDON

Printed in the United States of America Printed on acid-free paper 